\title{
Effect of graded levels of differently processed Roselle (Hibiscus sabdariffa) seed meal on the performance and carcass characteristics of broiler chickens \\ "Owosibo, A. O., ${ }^{* *}$ Okere, I. A. and Adedokun, G. A.* \\ "Department of Animal Production, Federal College of Animal Health and Production Technology, Moor Plantation, Ibadan, Nigeria.

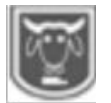 \\ ${ }^{* *}$ Livestock Improvement Programme, Institute of Agricultural Research and Training, Obafemi Awolowo University, Moor Plantation, P.M.B. 5029, Ibadan, Nigeria. \\ Abstract
}

The study was conducted to determine the effect of graded levels of differently processed Roselle (Hibiscus sabdariffa) seed meal on the performance and carcass characteristics of broiler chickens. One hundred and fifty (150), 28-day old birds were randomly allotted to 5 dietary treatments of 3 replicates of thirty birds each. Each replicate had 10 birds. The treatments were: T1 - control diet with $0 \%$ inclusion level of Roselle Seed Meal (RSM) while the four other diets had 50\% of raw (T2: rRSM), soaked (T3: sRSM), boiled (T4: bRSM) and fermented (T5: fRSM) Roselle Seed Meal in a complete randomized design. At the end of the 28 thday of the feeding (week 8), parameters measured were on performance and carcass characteristics. The data collected were analyzed using ANOVA of SAS with the means, where significant, were separated using the Duncan's Multiple Range Test. Final weight $(F W)$ and weight gain $(W G)$ were highest in birds on T5. Birds on T5 had the least feed conversion ratio (FCR) value (2.62). Feed intake and percent mortality did not differ significantly among birds on the different dietary treatments. Birds on T5 had significantly ( $p$ $<0.05)$ higher values for live weight $(L W)$, thigh weight $(T W)$ and neck weight $(N W)$. Percentage eviscerated weight, breast weight, drumstick weight, shank weight, wing weight and back weight did not differ significantly among the birds on the different treatments. The gizzard $(G)$, liver $(L)$ and spleen $(S)$ had the highest values in birds on T3 (G: 2.53\%), T1 (L: $2.34 \%$ ), T5 (S: 0.18) being significantly ( $p<0.05$ ) different from T5 (G: $2.04 \%$ and $L: 1.87 \%$ ), T2 (S: $0.08 \%), T 3$ (S: $0.08 \%)$ and T4 (S: 0.09\%) respectively. There were no significant $(p>0.05)$ differences observed among the treatments for percentage heart weight. It can be concluded that processing methods enhanced the utilization of Roselle seed meal with the best being the fermentation method as revealed by its feed conversion ratio, live weight and some carcass parameters when Roselle Seed Meal was substituted for 50\% of soybean meal in the broiler finisher diets.

Keywords: Broiler performance, carcass characteristics, differently processed and Roselle seed meal.

\section{Introduction}

The poultry industry depends on compounded rations for feed. A large proportion of these compounded rations comprise feed ingredients like maize, soyabean, groundnut cake etc. Soyabean is one of the major and most widely utilised conventional protein ingredients in poultry diets. It has however become very expensive over the years because it is a commodity that serves as food for humans, feed for livestock and raw material for the food processing industry; a factor that impacts negatively on the price of poultry products. This has led to the search for alternatives to it in order to reduce poultry production cost and also to reduce the competition between man and animals for the available conventional sources (Akande etal., 2013).

Malnutrition is an abnormal physiological condition caused by deficiencies or 
imbalances in energy, protein and or other nutrients. Protein malnutrition is one of the major problems facing most the developing countries because of the low animal protein intake. Meat, among other edible animal products, provides proteins with satisfactory amino acid profile as well as bioavailable micronutrients such as iron, zinc, calcium and vitamin A which maybe deficient in malnourished people. Thus, there is need to look for locally available and cheap sources of feed ingredients particularly those that do not attract competition between humans and livestock. One of such ingredients is Roselle (Hibiscus sabdariffa L.) seeds.

Roselle (Hibiscus sabdariffa) is a leguminous shrub that is cultivated in Nigeria and some other countries of the world (Akanya et al., 1997; Fasoyiro et al., 2005). The fermented Roselle seeds are used to make a cake known as sorrel 'meat' or 'iyu' as it is called by the Taroh people of Plateau state, Nigeria (Ashom et al., 2014). Roselle seeds contain high amounts of protein, dietary fibre and minerals such as phosphorus, calcium and magnesium. The seeds have also been used as a source of protein for broiler chicken production (Ismail et al., 2008; Diarra et al., 2011, Owosibo et al., 2017). The phytochemical screenings on the raw seeds have been reported to contain hibiscin, hydroxyl flavones and tannins as anti-nutritional factors (Mahadevan et al., 2009). The most commonly reported anti-nutritional factors are total phenols, tannins and phytic acid and these have had adverse effects on the health and performance of animals (Diarra et al., 2011 and Ismail et al., 2008). However, to inactivate anti-nutritional factors, various processing methods of test ingredients used in livestock feed have been employed (Soetan and Oyewole 2009; Duwa et al., 2012). Processing methods such as soaking, fermenting, cooking and sprouting have been reported to be effective (Ismail et al., 2008 and Diarra et al., 2011). Thus, optimising bioavailability of nutrients through improved processing of unconventional feed ingredients such as Roselle seed meal to enhance performance, carcass and internal organ characteristics to meet the need of consumers is paramount. Thus, the study evaluated the performance, carcass and internal organ characteristics of broiler chickens fed differently processed Roselle (Hibiscus sabdariffa) seed meal.

\section{Materials and methods Experimental site}

The experiment was carried out at the Teaching and Research Farm of the Federal College of Animal Health and Production Technology, Moor Plantation, Ibadan, Nigeria.

\section{Source and processing of Roselle seeds}

Roselle seed was purchased from Bodija Market, Ibadan, Oyo state, Nigeria. The seeds were cleaned and processed. Raw Roselle Seed Meal (rRSM): The cleaned seeds were milled and labelled (rRSM); Soaked Roselle Seed Meal (sRSM): The cleaned seeds were soaked in tap water for 24 hours, drained and sundried for 72 hours (3 days) then milled and labeled (sRSM); Boiled Roselle Seed Meal (bRSM): The cleaned seed was boiled in water at $100^{\circ} \mathrm{C}$ for 30 minutes, then drained and sun-dried for 72 hours (3 days). Dried samples were milled and labelled (bRSM); Fermented Roselle Seed Meal (fRSM): The cleaned seeds were boiled in water at $100^{\circ} \mathrm{C}$ for 30 minutes then washed and kept in an air-tight container to ferment for 3 days. Fermented seeds were then sun-dried for 72 hours, milled and labeled fRSM.

\section{Experimental diet}

There were five dietary treatments: $\mathrm{T} 1, \mathrm{~T} 2$, $\mathrm{T} 3$, T4, and T5. The diets were formulated such that $50 \%$ of the soyabean meal portions of the diets were replaced with 


\section{Owosibo, Okere and Adedokun}

Roselle Seed Meal (Table 1).

T1 had 0\% inclusion of Roselle seed meal; $\mathrm{T} 2$ had 50\% inclusion of raw Roselle seed meal; T3 had 50\% inclusion of soaked
Roselle seed meal; T4 had 50\% inclusion of boiled Roselle seed meal; T5 had 50\% inclusion of fermented Roselle seed meal.

Table 1: Gross composition of the broiler finisher experimental diets

\begin{tabular}{llllll}
\hline Ingredients (\%) & \multicolumn{5}{c}{ Treatments } \\
\cline { 2 - 6 } & T1(control) & T2(rRSM) & T3 (sRSM) & T4(bRSM) & T5(fRSM) \\
\hline Maize & 57.50 & 57.50 & 57.50 & 57.50 & 57.50 \\
Soybean meal & 25.00 & 12.50 & 12.50 & 12.50 & 12.50 \\
Roselle seed meal & - & 12.50 & 12.50 & 12.50 & 12.50 \\
Fish meal (72\%) & 1.50 & 1.50 & 1.50 & 1.50 & 1.50 \\
Wheat offal & 11.00 & 11.00 & 11.00 & 11.00 & 11.00 \\
Bone meal & 2.80 & 2.80 & 2.80 & 2.80 & 2.80 \\
Limestone & 1.50 & 1.50 & 1.50 & 1.50 & 1.50 \\
Lysine & 0.10 & 0.10 & 0.10 & 0.10 & 0.10 \\
Methionine & 0.10 & 0.10 & 0.10 & 0.10 & 0.10 \\
Salt & 0.25 & 0.25 & 0.25 & 0.25 & 0.25 \\
Broiler premix & 0.25 & 0.25 & 0.25 & 0.25 & 0.25 \\
Calculated analysis & 100.00 & 100.00 & 100.00 & 100.00 & 100.00 \\
Crude protein & 19.70 & 19.24 & 19.24 & 19.24 & 19.24 \\
ME (Kcal/kg) & 2828.15 & 2828.15 & 2828.15 & 2828.15 & 2828.15 \\
\hline
\end{tabular}

rRSM: raw Roselle Seed Meal, sRSM: soaked Roselle Seed Meal, bRSM: boiled Roselle Seed Meal, fRSM: fermented Roselle Seed Meal. ME: Metabolizeable Energy.

\section{Experimental animals and management}

A total of two hundred (200) day-old broiler chicks was purchased from a reputable hatchery. The chicks were brooded for two weeks using electric bulbs and charcoal as heat sources. The chicks were given uniform formulated starter diets (commercial feed) for four weeks before the experimental diets were introduced. At the end of the four weeks, one hundred and fifty (150) healthy birds were weighed individually and randomly allotted to five dietary treatments in groups of 30 chicks with 3 replicates of 10 chicks each in a completely randomised design (CRD). The birds were fed ad-libitum and fresh water provided on a daily basis.

\section{Performance and carcass characteristics}

The weight gain was recorded on a weekly basis. It was done by subtracting the initial live weight from final weight of the birds in each replicate. The weight gain in each replicate was divided by the number of birds in each replicate and this was the average weight gain of each bird in the replicate. The feed intake was derived by subtracting the remnant from the feed offered. This was done on a weekly basis. The amount of feed taken by the birds throughout the experiment was determined by dividing the number of birds in the replicate to get the average feed intake per bird throughout the experiment. The feed conversion ratio was calculated by dividing the feed intake by the weight gain.

At the end of the 28-day feeding trial being 8 weeks, two birds were selected randomly from each replicate for carcass evaluation after 12 hours of feed withdrawal in order to prevent contamination with feaces and feed in the intestine or crop during slaughtering. The carcasses were scalded in boiling water for about 30 seconds for easy de-feathering and evisceration. Data collected were live weight, carcass weight, eviscerated weight, breast, thigh, drumstick, wing, back, neck, shank and head weights as well as the weights of some of the internal organs (gizzard, liver, heart and spleen) which were expressed as a percentage of the live 


\section{Effect of graded levels of differently processed Roselle (Hibiscus sabdariffa) seed meal}

weight.

\section{Statistical analysis}

All data were subjected to one-way Analysis of Variance (ANOVA) using the General linear model of SAS (version 8, 1999) and means, where significant, were separated using the Duncan's Multiple Range Test of the same software.

\section{Results}

Proximate composition of differently processed Roselle seed meal

The results showed that there was an increase in Moisture content (MC), Crude protein $(\mathrm{CP})$, Ether extract (EE) and Crude fibre $(\mathrm{CF})$ in an increasing order across the treatment (Raw > Soaked > Boiled > Fermented) while a decreasing trend was observed for Nitrogen Free Extract i.e. (Raw < Soaked < Boiled < Fermented) Roselle seed meal. The Ash content was highest in percent value for boiled Roselle seed meal $(5.77 \%)$ with the least value in percent been raw Roselle seed meal (Table 2).

Proximate composition of broiler finisher diets

Treatment 1 had the highest dry matter content percentage of $91.87 \%$ which served as the control (Soyabean meal) while T4 had the least value of $90.97 \%$. Table 3 shows the proximate composition of broiler finisher diets.

Table 2: Proximate composition of differently processed Roselle seed meal

\begin{tabular}{lllll}
\hline & \multicolumn{4}{c}{ Treatments } \\
\cline { 2 - 5 } Parameters \% & Raw & Soaked & Boiled & Fermented \\
\hline Moisture Content & 8.07 & 8.37 & 8.40 & 8.77 \\
Crude Protein & 17.70 & 19.10 & 20.27 & 22.44 \\
Ether extract & 10.97 & 12.63 & 14.30 & 15.60 \\
Ash & 5.30 & 5.70 & 5.77 & 5.50 \\
Crude fiber & 9.80 & 10.70 & 11.47 & 11.87 \\
Nitrogen free extract & 48.10 & 43.47 & 39.77 & 37.50 \\
\hline
\end{tabular}

Table 3: Proximate composition of broiler finisher diets

\begin{tabular}{llllll}
\hline & \multicolumn{5}{c}{ Treatments } \\
\cline { 2 - 6 } Parameters & T1 & T2 & T3 & T4 & T5 \\
\hline Moisture Content (\%) & 8.13 & 8.73 & 8.43 & 9.03 & 8.43 \\
Crude Protein (\%) & 18.43 & 20.43 & 22.27 & 19.6 & 20.53 \\
Ether Extract (\%) & 7.43 & 9.57 & 10.53 & 10.43 & 9.73 \\
Ash (\%) & 5.30 & 5.47 & 5.50 & 5.47 & 5.67 \\
Crude fibre (\%) & 7.37 & 7.70 & 8.70 & 7.50 & 7.47 \\
Nitrogen Free Extract (\%) & 53.30 & 48.07 & 45.20 & 47.97 & 48.17 \\
\hline
\end{tabular}

Table 4 shows the performance characteristics of broiler chickens fed raw or differently processed Roselle seed mealbased diets. The results for final weight (FW) and weight gain (WG) were highest in T5 (FW: $1.87 \mathrm{~kg}$ and WG: $1.26 \mathrm{~kg}$ ) and was significantly $(\mathrm{p}<0.05)$ different from the values of birds on $\mathrm{T} 2(\mathrm{FW}: 1.71 \mathrm{~kg}$ and WG: $1.09 \mathrm{~kg}$ ) and T3 (FW: $1.73 \mathrm{~kg}$ and WG: $1.11 \mathrm{~kg})$ but was not significantly $(\mathrm{p}>0.05)$ different from those of T4 (FW: $1.79 \mathrm{~kg}$ and WG: $1.18 \mathrm{~kg}$ ) and T1 (FW: $1.86 \mathrm{~kg}$ and WG: $1.24 \mathrm{~kg}$ ). Birds on T5 had the least value of feed conversion ratio (FCR) (2.62). This is significantly $(\mathrm{p}<0.05)$ different from that of birds on T2 (3.03) and T3 (2.96) but was not significantly $(\mathrm{p}>0.05)$ different from that of birds on T1 (2.76) and T4 (2.82). There were no significant $(\mathrm{p}<0.05)$ differences observed among the treatments for feed intake and percent mortality. 


\section{Owosibo, Okere and Adedokun}

Table 4: Performance characteristics of broiler chickens fed differently processed Roselle (Hibiscus sabdariffa) Seed Meal Based-Diets

\begin{tabular}{lllllll}
\hline & \multicolumn{7}{c}{ Treatments } \\
\cline { 2 - 6 } Parameters & $\mathrm{T} 1$ & $\mathrm{~T} 2$ & $\mathrm{~T} 3$ & $\mathrm{~T} 4$ & $\mathrm{~T} 5$ & $\mathrm{SEM}$ \\
\hline Initial weight $(\mathrm{kg})$ & 0.63 & 0.63 & 0.62 & 0.61 & 0.62 & 1.67 \\
Final weight $(\mathrm{kg})$ & $1.86^{\mathrm{a}}$ & $1.71^{\mathrm{b}}$ & $1.73^{\mathrm{b}}$ & $1.79^{\mathrm{ab}}$ & $1.87^{\mathrm{a}}$ & 20.71 \\
Weight gain $(\mathrm{kg})$ & $1.24^{\mathrm{a}}$ & $1.09^{\mathrm{c}}$ & $1.11^{\mathrm{bc}}$ & $1.18^{\mathrm{ab}}$ & $1.26^{\mathrm{a}}$ & 21.23 \\
Feed Intake $(\mathrm{kg})$ & 3.39 & 3.29 & 3.28 & 3.34 & 3.29 & 22.85 \\
Feed Conversion Ratio & $2.76^{\mathrm{ab}}$ & $3.03^{\mathrm{a}}$ & $2.96^{\mathrm{a}}$ & $2.82^{\mathrm{ab}}$ & $2.62^{\mathrm{b}}$ & 0.05 \\
Mortality $(\%)$ & 3.33 & 0.00 & 0.00 & 3.33 & 0.00 & 0.91 \\
\hline a,b,c Means on the same row with different superscripts differ significantly $(\mathbf{p}<\mathbf{c 0 . 0 5})$ & & & &
\end{tabular}

The results of the carcass characteristics show that the weight of the chickens (expressed as percentage of live weight yield of carcass and cut-up parts) was significantly affected by the dietary treatments (Table 5). The live weight (LW), thigh weight (TW) and Neck weight (NW) for birds on T5 had the highest values (LW: $1.61 \mathrm{~kg}$, TW: $11.87 \mathrm{~kg}$ and NW: $4.36 \%$ ). These values were significantly $(\mathrm{p}<0.05)$ different from the values obtained in birds on T1 (TW: $10.48 \%$ and NW: $3.32 \%$ ), T3 (LW: $1.41 \mathrm{~kg}$ ) and T4 (LW: $1.42 \mathrm{~kg}$ and TW: $10.36 \%$ ). The head weight (HW) was highest in birds on T4 (2.88\%) and was significantly $(\mathrm{p}<0.05)$ different from that of birds on T5 $(2.30 \%)$. There were no significant $(\mathrm{p}>0.05)$ differences observed among the treatments for eviscerated weight, breast weight, drumstick weight, shank weight, wings weight and back weight.

Table 5: Carcass characteristics of broiler chickens fed differently processed Roselle (Hibiscus sabdariffa) seed meal based-diets

\begin{tabular}{lllllll}
\hline & \multicolumn{7}{c}{ Treatments } \\
\cline { 2 - 6 } Parameters & T1 & T2 & T3 & T4 & T5 & SEM \\
\hline Live weight (kg) & $1.51^{\mathrm{ab}}$ & $1.52^{\mathrm{ab}}$ & $1.41^{\mathrm{b}}$ & $1.42^{\mathrm{b}}$ & $1.81^{\mathrm{a}}$ & 61.41 \\
Plucked weight (plw) & $94.45^{\mathrm{a}}$ & $92.90^{\mathrm{ab}}$ & $87.12^{\mathrm{b}}$ & $94.06^{\mathrm{ab}}$ & $93.24^{\mathrm{ab}}$ & 1.18 \\
Eviscerated weight (plw) & 65.70 & 68.87 & 64.50 & 64.17 & 69.02 & 1.11 \\
Breast weight (plw) & 20.24 & 19.83 & 17.95 & 18.70 & 17.86 & 0.55 \\
Thigh weight (plw) & $10.48^{\mathrm{b}}$ & $11.21^{\mathrm{ab}}$ & $10.66^{\mathrm{ab}}$ & $10.36^{\mathrm{b}}$ & $11.87^{\mathrm{a}}$ & 0.22 \\
Drumstick weight (plw) & 10.34 & 10.09 & 10.62 & 9.89 & 10.76 & 0.16 \\
Head weight (plw) & $2.53^{\mathrm{ab}}$ & $2.55^{\mathrm{ab}}$ & $2.68^{\mathrm{ab}}$ & $2.88^{\mathrm{a}}$ & $2.30^{\mathrm{b}}$ & 0.07 \\
Shank weight (plw) & 4.47 & 4.49 & 4.36 & 4.55 & 4.25 & 0.11 \\
Wing weight (plw) & 8.63 & 8.40 & 8.35 & 8.27 & 8.38 & 0.08 \\
Back weight (plw) & 16.22 & 15.51 & 16.51 & 16.91 & 17.23 & 0.32 \\
Neck weight (plw) & $3.32^{\mathrm{b}}$ & $4.17^{\mathrm{a}}$ & $4.22^{\mathrm{a}}$ & $4.12^{\mathrm{a}}$ & $4.36^{\mathrm{a}}$ & 0.10 \\
\hline a,b,c, Means on the same row with different superscripts differ significantly (p< $\mathbf{0 . 0 5})$ & & &
\end{tabular}

The results of some internal organs show that the weight of the chicken expressed as percent of live weight yield of carcass and cut-up parts was significantly affected by the dietary treatments (Table 6). The gizzard $(\mathrm{G})$, liver $(\mathrm{L})$ and spleen $(\mathrm{S})$ had the highest values in birds on T3 (G: 2.53\%), T1 (L: 2.34\%), T5 (S: 0.18) being significantly $(\mathrm{p}<0.05)$ different from $\mathrm{T} 5$ (G: $2.04 \%$ and L: $1.87 \%$ ), T2 (S: $0.08 \%$ ),
T3 (S: 0.08\%) and T4 (S: 0.09\%) respectively. There were no significant $(\mathrm{p}>$ 0.05) differences observed among the treatments for percent heart weight.

\section{Discussion}

Proximate

Proximate composition of the differently processed Roselle seed meal showed an increase in the protein content and lower 
Effect of graded levels of differently processed Roselle (Hibiscus sabdariffa) seed meal

Table 6: Effect of differently processed Roselle seed ( Hibiscus sabdariffa) meal-based diets on some internal organs of broiler chickens

\begin{tabular}{lllllll}
\hline & \multicolumn{5}{c}{ Treatments } \\
\cline { 2 - 6 } Parameters & T1 & T2 & T3 & T4 & T5 & SEM \\
\hline Live weight (Kg) & $1.51^{\mathrm{ab}}$ & $1.52^{\mathrm{ab}}$ & $1.41^{\mathrm{b}}$ & $1.42^{\mathrm{b}}$ & $1.81^{\mathrm{a}}$ & 61.41 \\
Plucked weight (PLW) & $94.45^{\mathrm{a}}$ & $92.90^{\mathrm{ab}}$ & $87.12^{\mathrm{b}}$ & $94.06^{\mathrm{ab}}$ & $93.24^{\mathrm{ab}}$ & 1.18 \\
Eviscerated weight (PLW) & 65.70 & 68.87 & 64.50 & 64.17 & 69.02 & 1.11 \\
Gizzard (PLW) & $2.35^{\mathrm{ab}}$ & $2.39^{\mathrm{ab}}$ & $2.53^{\mathrm{a}}$ & $2.32^{\mathrm{ab}}$ & $2.04^{\mathrm{b}}$ & 0.06 \\
Liver (PLW) & $2.34^{\mathrm{a}}$ & $2.16^{\mathrm{a}}$ & $2.32^{\mathrm{a}}$ & $2.24^{\mathrm{a}}$ & $1.87^{\mathrm{b}}$ & 0.08 \\
Heart (PLW) & 0.41 & 0.46 & 0.49 & 0.44 & 0.47 & 0.02 \\
Spleen (PLW) & $0.16^{\mathrm{a}}$ & $0.08^{\mathrm{b}}$ & $0.08^{\mathrm{b}}$ & $0.09^{\mathrm{b}}$ & $0.18^{\mathrm{a}}$ & 0.02 \\
a,b,c, Means on the same row with different superscripts differ significantly $(\mathbf{p}<\mathbf{0 . 0 5})$. PLW: Percentage of live weight
\end{tabular}

nitrogen free extracts content which might be as a result of the different processing methods.

\section{Performance of finisher broiler chickens}

The weight gain and final weight were significantly $(\mathrm{P}<0.05)$ higher in birds on T5 than in birds on the other diets. This trend is contrary to the reports of Kwari et al. (2011) and Ashom et al. (2014) where there were no significant differences observed in weight gain and final weight among the finisher broilers fed the differently processed Roselle seed meal.

Feed intake obtained was slightly higher than those reported by Ashom et al. (2014) and Duwa et al. (2012) for finisher broiler chickens fed processed roselle seeds. Ashom et al. (2014) reported significantly $(\mathrm{P}<0.05)$ higher feed intake for birds fed diets containing sprouted and boiled Roselle seeds than those on the control diet (raw and soaked Roselle seed meal). This observation is contrary to the findings of this study where no significant difference was observed in the feed intake among birds on the dietary treatments.

Feed conversion ratio obtained are slightly higher than those reported by Duwa et al. (2012) (2.61 - 2.85) and slightly lower than those reported by Ashom et al. (2014) (3.16 $-2.69)$ for finisher broilers but similar to a range of 2:1 (Oluyemi and Roberts 2000) and 3:1 (Banerjee 1998). A significantly ( $P$ $<0.05)$ lower value was obtained for birds fed diets containing the fermented Roselle seed meal. This implies better feed utilisation. This is contrary to the reports of Kwari et al. (2011) and Ashom et al. (2014) that feed conversion ratio significantly increased on diets based on the fermented and sprouted seeds. Duwa et al. (2012) did not find any significant difference in feed conversion ratio of finisher broilers among birds fed raw, roasted, boiled and soaked Roselle seed-containing diets. Feed conversion ability was poorly affected in the raw (T2) and soaked (T3) Roselle seed meal which ultimately led to a significantly $(\mathrm{P}<0.05)$ lower final weight of birds. This trend is contrary to the reports of Kwari et al. (2011) and Ashom et al. (2014) that observed no significant differences in final weight of finisher broilers fed differently processed roselle seed meals.

\section{Carcass characteristics}

It was observed that the weight yield of carcass and cut-up parts were significantly affected by the dietary treatments particularly in terms of thigh weight and head weight. Birds on the dietary treatment with fermented Roselle seed meal (T5) had the most appreciable percent live weight. This observed trend differs from the trend reported by Ashom et al. (2014) who reported a insignificant difference in terms of thigh weight in a study where processed Roselle seed meal was fed to broiler finishers. The plucked weights were 


\section{Owosibo, Okere and Adedokun}

slightly above the upper limit of $91.99 \%$ and slightly below the lower limit of 88.76\% reported by Ashomet al. (2014).

The weights of the drumsticks and thighs obtained are slightly lower than 11.67 and $12.95 \%$ respectively reported by Oluyemi and Roberts (2000) but are similar to that reported Ashom et al. (2014). The weights of the wings, breast and back are higher than $8.21,17.40$ and $12.05 \%$ reported by Oluyemi and Roberts (2000). However, the weight of the breast meat obtained was slightly higher than $17.88 \%$ reported by Ashom et al. (2014). The results of this study showed that replacing $50 \%$ of soyabean meal with raw, soaked, boiled and fermented roselle seeds in finisher broiler diets did not have any negative effect on carcass weights of finished broilers.

\section{Internal Organ Characteristics}

Significant $(\mathrm{P}<0.05)$ differences were observed in the weights of the gizzard, liver and spleen of the birds on the dietary treatments. Gizzard weight was significantly $(\mathrm{P}<0.05)$ higher in birds fed diets containing soaked Roselle seed meal than in birds fed the fermented Roselle seed meal. Ashom et al. (2014) reported higher empty gizzard weights for birds fed boiled Roselle seed meal diets than those fed raw and sprouted. The liver was significantly $(\mathrm{P}$ $<0.05)$ higher in the birds fed the raw, soaked and boiled roselle seed meal than in the birds fed the fermented Roselle seed meal. This trend differs from the report of Ashom et al. (2014) where no significant differences were observed among the dietary treatments. The weight of the heart showed no significant $(\mathrm{P}<0.05)$ differences in the birds on the dietary treatments. This conforms to the report of Ashom et al. (2014) with the range of $0.47-0.52 \%$ being slightly higher than $0.41-0.49 \%$ of the heart weight as expressed as a percentage of the live weight.

The spleen weight was significantly
$(\mathrm{P}<0.05)$ higher in birds fed the fermented Roselle seed meal. This could be attributed to stress on the spleen to produce more enzymes to compensate for enzyme inactivation by anti-nutrients present in the fermented seeds. However, this observation differs from the norm that spleen weight increases when there are anti-proteolytic substances in the diets. Also, contrary report was made by Ashom et al. (2014) that processing methods such as sprouting and boiling Roselle seeds were more effective at decreasing pancreas size; an indication of inactivation of anti-nutritional factors than by unprocessed and soaking processing methods.

\section{Conclusion}

The growth rate of the broiler finishers was not affected adversely with 50\% inclusion level of Roselle seed meal as replacement for Soybean in the diet. Processing methods enhanced the utilisation of Roselle seed meal with fermentation method being the best in terms of final weight, weight gain, feed conversion ratio, live weight, weights of carcasses and cut-up parts, and some internal organ. Thus, fermented roselle seed meal can replace soyabean meal in broiler diet at 50\% inclusion rate without eliciting any adverse effects on the birds.

\section{References}

Akande T. O., Odunsi, A.A., Rafiu, T. A., Olaniyi, C. O. and Binuomote, R. T. 2013. Growth and serological assessment of broiler chickens fed differently processed castor (Ricinuscommunis Linn.) kernel cake-based diets. African Journal of Agricultural Research, 8 (14), pp. $5161-5165$.

Akanya H. O., Oyeleke, S. B., Jigam, A. A. and Lawal, F. F. 1997. Analysis of sorrel drink (Zoborodo) Nig. J. Biochem, 12, pp. 77-81. 
Ashom, S. A., Tuleun, C. D. and Carew, S. N. 2014. Growth, carcass and internal organ 50characteristics of finisher broiler chickens fed processed Roselle (Hibiscus sabdariffa L.) seed meal diets. Journal of Biology, Agriculture and Healthcare, 4(24), pp. $141-146$.

Banerjee, G. C. 1998. A Textbook of Animal Husbandry,8th edition. Oxford and IBH Publishing Company, PVT Ltd, New Delhi, 1079pp.

Diarra, S. S., Kwari, I. D., Girgiri, Y. A., Saleh, B. and Igwebuike, J. U. 2011. The use of sorrel (Hibiscus sabdariffa) seed as a feed ingredient for poultry: A review, Research Opinions in Animal and Veterinary Sciences, 1(9), 573-577.

Duwa, H., Oyawoye, E. O. and Njidda, A. A. 2012. Haematological responses and serum biochemical indices of broilers fed differently processed sorrel seed (Hibiscus sabdariffa) meal in semi-arid region of Nigeria, BritishJournal of Poultry Sciences 1(1), 05-10.

Fasoyiro S. B., Babalola S. O. and Owosibo, T. 2005. Chemical composition and sensory quality of fruit-flavoured Roselle (Hibiscus sabdariffa) Drinks. World Journal of Agricultural Sciences, 1 (2): 161 164.

Ismail, A. E., Ikram, H. K. and Nazri, H. S. M. 2008. Roselle (Hibiscus sabdariffaL.) seeds - Nutritional composition, protein quality and health benefits, Food, 1-16.

Kayembe, N. C. 2011. Germination as a processing technique for soybeans in small-scale broiler farming, M.Sc. Inst. Agrar Dissertation, University of Pretoria, South Africa.

Kwari, I. D., J. U. Igwebuike and Diarra,
S. S. 2010. Growth performance and carcass measurements of broiler chickens fed different levels of raw sorrel (Hibiscus sabdariffa) seed meal, Journal of Environmental Issuesand Agriculture in Developing Countries, 2 (2 \& 3), $162-168$.

Kwari, I. D., Igwebuike, J. U., Mohammed, I. D. and Diarra, S. S. 2011. Growth, hematology and serum biochemistry of broiler chickens fed raw or differently processed sorrel (Hibiscus sabdariffa) seed meal in a semi-arid environment, International Journal of Science and Nature, 2(1), 22-27.

Mahadevan, N., Shivali and Kamboj, P. 2009. Hibiscus sabdariffa Linn - An overview, Natural Product Radiance, 8(1), $77-83$.

Oluyemi, J. A. and Roberts, F. A. 2000. Poultry Production in Warm Wet Climates, 2nd edition, Spectrum Books Limited, 244pp.

Owosibo A. O., Okere, I. A. and Adedokun, C. A. 2017. Effect of graded levels of raw Roselle (Hibiscus sabdariffa) seed meal on performance, carcass characteristics and meat quality traits of broiler chickens. Nigerian Journal of Animal Production, 44 (1), 141 150.

SAS Institute 1999. SAS/STAT users guide. Version 8 SAS Institute Inc. Cary, N.C.

Soetan, K. O. and Oyewole, O. E. 2009. The need for adequate processing to reduce the anti-nutritional factors in plants used as human food and animal feeds: A review, African Journal of Food Science, 3(9), 223 232.

Received: $4^{\text {th }}$ November, 2017

Accepted: $2^{\text {nd }}$ March, 2018 